\title{
Networking African journalism educators: bonding, bridging, and linking
}

\author{
Guy Berger
}

\begin{abstract}
Professional networking of African journalism educators is a complex matter for reasons related to the fragmentary identity and fragile resource base of this constituency. African journalism educators thus share many characteristics which ironically dilute the sense of a clear and common identity that could facilitate networking as a community. The prospects for building a social network amongst this constituency can be analysed in terms of theories of social capital and a review of various experiences. The results suggest that "bridging" to external constituencies with resources is the most fertile method of community creation, and this driver is central to building social capital via enhanced relationships in the African journalism education sector.
\end{abstract}

\section{Keywords}

Identity, journalism education, media, networking, social capital, UNESCO, World Journalism Education Congress

\section{Introduction}

An interest in networking African journalism educators is based on the assumption that increased connectedness can strengthen their work and that this in turn can help improve journalism on the continent. However, this article's purpose is not to investigate this assumption as such, but rather to assess what factors appear to contribute to building a networked community of practice amongst African journalism educators. An analysis of 
these factors may help conceptually in terms of further research into the underlying assumption about significance.

Journalism teachers around Africa are confronted with interpreting and teaching journalism in a context that is globally marginalised and widely characterised by democratic deficits, low media densities, high pluri-lingualism, and development problems like AIDS and widespread poverty. A key issue is the shadow of negative global imaging of Africa, along with the race and identity assumptions that go with this. Seen against this backdrop, a formal organisation of African journalism educators could perhaps help address some of these issues, but the obstacles to this level of institutionalised networking are immense. On the other hand, even a lesser level of networking might nevertheless play a valuable role. Online social network facilities for this sector have been created by UNESCO, and a portal for African media information is being set up by the African Union and European Union. However, the prospects for effective exploitation of these and other resources depend in part on the identities and interconnections of African journalism educators. This article explores what factors impact on building a network of practitioners within this particular sector. There are several studies related to journalism education in Africa (see below) but there appears to be nothing as yet on the social relationships characterising the sector (besides for teacher-student relations ${ }^{1}$ ). This lacuna underlines the value of the contribution this article seeks to make. Therefore, the article is not about African journalism or journalism education issues but rather about the identity and connections related to the teachers of journalism.

\section{Analysis of the constituency}

As noted by many scholars, variations in identities and languages, and in educational and media regimes, are particularly acute across the 55 nation-states in Africa (see, for example, Bourgault, 1995; Nyamnjoh, 2005). There is also a vastness of geographical scale and rural demography, which compounds the general underdevelopment of communications at large. In this context, therefore, it is not surprising that journalism educators face many challenges. Examples of this include inadequate production equipment as well as poorly-funded

\footnotetext{
${ }^{1}$ See for example Njugana, 2010; Amner, 2010.
} 
institutions with massively oversubscribed classes and educators overloaded with teaching duties (See UNESCO, 2007; Skjerdal and Ngugi, 2007) ${ }^{2}$.

These particularities intensify more general complexities endemic to the general character of journalism educators. The people in this occupation typically relate to the institutional base of a tertiary education facility and, at least in principle, also to a highly variegated industry. In many African countries, this industry is not only internally delineated by medium (print, broadcast, online) but also by ownership and role distinctions along the lines of public, commercial, and community platforms.

What this means is that journalism educators, not least in Africa, are often pushed and pulled between many different centres of gravity. The media (in all their diversity) often regard the sector as a (less-than-successful) service provider to their labour-power needs. The academy, however, often has a less instrumentalist and more creative view of its role in knowledge generation and dissemination. Students are a third factor, with their own several interests and viewpoints. As if this nexus were not complex enough, most journalism educators also work in facilities which teach more than journalistic communications. For example, they also cover public relations or business communication, and -- often in Africa -- they wrestle with teaching the interlinkage of communications and development (see Wimmer and Wolf, 2005; McCurdy and Power, 2005). Complicating matters further, African journalism educators are also pulled between dependence on Western models and materials on the one hand, and appeals to African-centricity on the other (see for example Murphy and Scotton, 1987; Okigbo and Pratt, 1997; Rabe, 2005; Skjerdal, 2009; Fosu, 2010; De Beer, 2010; Dube, 2010; Oyelele, 2011).

The subject of networking journalism educators therefore hinges on whether the practice of journalism education within this broader context of communication educators (and not least in Africa) is sufficiently distinctive to constitute a coherent constituency. But even those teachers who teach journalism practice are often divided between those in television versus

\footnotetext{
${ }^{2}$ Analysis of data collected for UNESCO by this author in 2007 revealed that of 188 identified journalism schools around Africa, only $15 \%$ had a degree of web presence -- usually via a parent institutional site, or very basic information on a dedicated online space. The cyberpresence amounted to a richer multi-purpose website for the school concerned in only $5 \%$ of the total.
} 
those print (and between these and new media teachers). And this is not to mention the gulfs that often exist between all of these and their more scholarly colleagues teaching media studies dimensions. The clear point that emerges from this, therefore, is that efforts to network journalism educators into a community of sorts are never going to be a simple matter -- anywhere in the world. In African conditions, this challenge is possibly even greater than elsewhere.

These factors explain why the identity of "African journalism educator" is an artifact, i.e. something requiring conscious and ongoing construction. This is not even to bring into the picture other, and often over-riding, identity dimensions -- such as the objectivity and subjectivity of being, for instance, a woman (journalism educator) or a French-speaking (journalism educator), etc. The extent to which an identity of being an African journalism educator can be developed and sustained, to the extent of constituting a community, is the question under investigation in this article.

The academic literature on journalism education in Africa is often dated, but it is also limited largely to descriptive (rather than analytical) reviews of the providers in a given country (especially South Africa) and to normative discussion around Africanising or updating the curriculum at particular institutions. ${ }^{3}$ Little attention appears to have been given to the educators themselves, and even less to the issue of interconnections amongst them and their institutions, and between both of these and external parties. This article attempts to partly remedy the gap by assessing selected experiences of, and potential for, networking (especially on a sub-Saharan basis).

In broader terms, it has been established above that the multiple pressures and influences on African journalism educators are likely to impact on the constituency of African journalism educators becoming a conscious entity for itself and not just existing as a descriptive category

\footnotetext{
${ }^{3}$ See, for example, Okigbo and Pratt, 1997; Hochheimer, 2001; Botha and de Beer, 2006; Rooney, 2007; Banda et al, 2007; Mojaye, 2009. In addition, reference is made to Fosu, 2010; Olusola 2010; Popoola 2010; Sibanda, 2010 and other papers presented at the World Journalism Education Congress in July 2010, available at: http://wjec.ru.ac.za/index.php?option=com_rubberdoc \&view=category\&id=9\%3Aafrican-jeducation\&Itemid=45 (Retrieved 11 July 2011 from the World Wide Web).
} 
within itself. Degrees of success in overcoming the hurdles, however, have been experienced in some developed country environments (like the USA, Canada, UK, Europe, and Australasia), but to go further and analyse the factors at play in Africa, a brief conceptual detour is needed.

\section{Annexing theory to the project}

Networks are theorised as relationships between individuals or individuals with shared interests, voluntary participation, and a degree of coherent action. They depend on a sense of ownership by participants, and also capacity and adaptability to sustain these relationships although -- and this is critical to the cause of networking African journalism educators -- a successful network itself also builds capacity (See Taschereau \& Bolger, 2006, cited in Wuite, 2008).

Insights into the possibilities of building networks can be discerned from the theorisation of networks and social capital. These emerge from the writings of Bourdieu (1980), Bourdieu \& Wacquant (1992), Putnam, (2000), Coleman (1998), and Field (2003). Notwithstanding differences within these theories, they generally highlight qualities like trust and reciprocity as preconditions for, and characteristics of, social capital emerging from networks. Add to this, a Marxist understanding of "capital" as having an incremental dynamic (see Berger, 2007b), and social capital in this sense can be seen to designate the sustained growth of collective general assets in which the active and increasing participation of each person or group further enriches the whole. It is apparent that societies, associations, institutions, etc. can all manifest social capital, and in varying degrees. Importantly, the inter-relationship between these different entities is also likely to affect social capital generation at any one particular scale (e.g. the unit of an association) within the whole.

The implicated relationships in social capital can be categorised qualitatively as "bonding", "bridging", and "linking". These terms may be seen as connection points along a continuum which reflects the degree of diversity of the participants. At one side, "bonding" designates connections amongst people in highly similar situations (e.g. amongst a family or within an institution) while the other end of the spectrum is characterised by connections between people in very different situations (for instance, with varying linguistic, occupational, 
national, etc., characteristics). Significantly, theorists of social capital propose that while bonding is good for unleashing certain mutual value, exceptional value can be gained by linking together those who are not alike. In other words, connections across differences, even if only bridging in extent, can prove to be sources of mutual benefit precisely because there are not usual or easy flows of resources (intellectual -- knowledge capital, or financial) across these kinds of divides.

These three kinds of relationships can be investigated at the level of individual African journalism teachers, individual journalism schools, schools within a given country categorised as a national sector, and the pan-African sector as a whole. Importantly, a different substance can be given to the meaning of bonding, bridging, and linking, as applied to each of these levels (and across them), depending on the kinds of connections being struck. For instance, there can -- in principle at least -- be bonding by individuals within a school or across schools, and there can be bonding between schools. Likewise, there can be bridging or linking between individual educators and/or between their institutions. On the other hand, as will be discussed later, the prospects for success of a given kind of relationship are not equal across all entities. As an illustration for now, it can be posited that it may well be more difficult to bond, than to bridge or link when there are divisions based on language or geographical barriers.

The relations between individual African journalism educators do not exist in a silo that is separate from what happens at other levels (and vice versa). However, independently to an extent of relations at the level of schools, it is possible to conceive of bonding, bridging, and linking on an entirely individual basis by a number of African journalism educators. The relationships may be within or across institutions, nations, and even extra-continental divides (especially with regard to the African diaspora). Individuals who make connections in this way can generate a lot of social capital but involvement of their institutions may also help to ensure fruitful relationships that are bigger than the specific persons involved. That, in turn, will logically depend on the capacity and interest of a given school.

In considering social capital generation at the level of an individual journalism school, it can be noted that there is a high correspondence here to UNESCO's criteria for excellence in 
African journalism education (see Berger \& Matras, 2007; Berger, 2007a; Berger, 2008b; Claussen, 2008). These criteria designate three areas where an African journalism school can work to achieve "excellence": internal strengths, external connections, and demonstrable sustainability. By relating the first of these to theories of social capital, it can be seen that the internal strength of a given school could be measured in terms of, inter alia, "bonding" among staff, bridging to students, and linking to other campus constituencies.

The second UNESCO criteria area entails "bridging" to the media industry and also "linking" to communities/NGOs/policy makers. The third UNESCO area, namely the sustainability of a school, is a function of the effectiveness of the internal strength and the external connections. For instance, effective bonding, linking, and bridging can help to secure a high standing of a given school with both the academy and with external partners, i.e. help to create relationships with these bodies that then serve to draw in resources on a durable and expanding basis. Reciprocity will be defined here by the value that a school can bring to these interlocutors and thence to the durability of relationships involved.

It is also possible to examine social capital relationships at the level of a national sector more broadly. For instance, there can be "bonding" between a given country's schools (notwithstanding rivalries) or "bridging" between schools across different nations. There is also the possibility of "linking" to mutual advantage between a national sector and other groups with a national presence (e.g. links to Human Rights advocacy groups).

A graphic illustration of the possibilities is presented in Table 1 below:

\begin{tabular}{|l|l|l|l|}
\hline & Per individual & Per-school & Sector \\
\hline BONDING & $\begin{array}{l}\text { E.g. With similar } \\
\text { colleagues }\end{array}$ & $\begin{array}{l}\text { E.g. Between the staff } \\
\text { and students of a } \\
\text { journalism school }\end{array}$ & $\begin{array}{l}\text { E.g. between national } \\
\text { schools }\end{array}$ \\
\hline BRIDGING & $\begin{array}{l}\text { E.g. With peers } \\
\text { who may be } \\
\text { different, or with }\end{array}$ & $\begin{array}{l}\text { E.g. with media } \\
\text { industry institutions }\end{array}$ & $\begin{array}{l}\text { E.g. between African } \\
\text { schools }\end{array}$ \\
\hline
\end{tabular}




\begin{tabular}{|l|l|l|l|}
\hline & $\begin{array}{l}\text { practising } \\
\text { journalists and } \\
\text { editors }\end{array}$ & & \\
\hline LINKING & $\begin{array}{l}\text { E.g. With } \\
\text { individuals in } \\
\text { foundations, non- } \\
\text { media companies, } \\
\text { civil society, state } \\
\text { actors. }\end{array}$ & $\begin{array}{l}\text { E.g. with communities, } \\
\text { NGOs, donors, etc. }\end{array}$ & $\begin{array}{l}\text { E.g. between African } \\
\text { schools and } \\
\text { UNESCO }\end{array}$ \\
\hline
\end{tabular}

Table 1: Possibilities for social capital relationships in journalism education

It is self-evident that building social networks through journalism education connections with a continental sector (for instance, with The Africa Editors Forum or the African Union's Commission for Human and People's Rights) is probably more complex than making connections inside a given country between individual journalism schools and their personnel. $^{4}$

One issue in all of this is the standing of journalism education with such external bodies. In turn, that relates to the image in the sector qua 'significant actor'. This sectoral image further rests on the question of solidarity and trust between schools within and across national boundaries and, by implication, the legitimacy of networking initiatives amongst them. Institutional and national inequalities, resentments and suspicion of motives can bedevil success here although these can be overcome by joint participation in decision-making (Taschereau \& Bolger, 2006, cited in Wuite, 2008). These points sensitise us to potential tensions in the activity of networking African journalism educators, something that impacts upon another ingredient with regard to networking for social capital formation, namely, reciprocity. Relationships based on inequality, patronage or exploitation are not good foundations for sustained networking. Yet, some African journalism schools have greater

\footnotetext{
${ }^{4}$ The importance of such connections is illustrated by a controversial initiative in $2008-9$ by the African Union and the European Union to set up a pan-African Media Observatory (see http://media-dev.eu). This attracted critical responses from a wide range of NGOs, but there was no formation that could generate organised or representative comments by African journalism educators. The result was an absence of views by the sector, and indeed of even knowledge of the initiative by journalism educators around the continent. In 2010, the initiative evolved into stressing media research and training, but again without specific input by the constituency with a very direct interest in these issues.
} 
access to networking resources than others. Unevenness in the sector affects not just capacity but confidence in the value of peer-networking.

\section{Selected experiences of building a community of journalism educators}

Against this background, it is possible to posit several ideas about what works and what does not work based on several past experiences of networking African journalism educators. As elaborated below, the evidence from these cases suggests that the role of external resources (i.e. "donor-centred" networking), and prospects for potential resources, are not only important enablers (i.e. the strength of "linking relationships") but to a large extent are also drivers of connections. In addition, contact with media practitioners (i.e. "bridging relationships") appears to promote networking. It is also apparent that networking works best on the basis of limited initiatives that do not place excessive demands on the participation of those educators and schools involved. Another contributing factor is where networking entails the power of pan-Africanist sentiment and aspiration. A sense of identity in terms of being in part of a "community-for-itself" vis-à-vis non-African "Others", has also been a powerful promoter for networking African journalism educators, albeit not consistently. In this pan-Africanism driver, the motivation to network and build social capital is experienced as a contribution to the "community" in terms of its place in the world, and not necessarily as something for material benefit of the individuals or institutions involved.

An example of the bridging, rather than bonding, imperative as generating results can be seen through a brief review of South African experience. The country has tried and failed to set up South African associations of journalism educators over the years. The moves in 1998 to create the Print Educators Association of South Africa (Petasa) and the Broadcast Educators and Trainers Association (Beta) failed. Likewise with a trial balloon floated by Lizette Rabe, head of the University of Stellenbosch's journalism school some years later. Slightly more successful, albeit temporarily, was the donor-financed Southern African Media Trainers Network (Samtran), which operated on-and-off in southern Africa from 2001 to circa 2008, bridging educators in the higher-education institutions with NGO and freelance trainers during this period. Another linking relationship that has involved social capital creation is that between journalism educators and other communications scholars meeting at the annual 
conferences of the South African Communication Association (SACOMM). Participation by key journalism schools there, however, has remained marginal -- suggesting that few journalism educators see sufficient value in investing in relationships with colleagues engaged in other communications specialisations.

Perhaps the most successful experience (albeit not always on a consistent level) within South Africa has been more than a decade's evidence of congregation by senior journalism educators (from various journalism schools) around the centre of gravity of the South African National Editors Forum (http://www.sanef.org.za). This appears to suggest that bridging with the industry has been seen by South African educators as more important than bonding with each other directly or by linking up to other kinds of communications experts at SACOMM. The educators' connections with each other (for instance in the Forum's Education and Training sub-committee) have been a secondary function of this larger involvement. This experience shows that external relations have been seen as more valuable than putting energies into formulating internal coherence, trust, and reciprocity within the journalism education sector itself. Social capital for these educators has instead been generated through their bridges with an industry leaders' network. ${ }^{5}$

In the Kenyan case, another case of bridging to industry has involved educators from four journalism schools who have participated in the statutory Media Council of Kenya. The council enlists individuals who hail from the journalism schools at the University of Nairobi and Daystar University (both recognised by UNESCO as having potential) and from the United States International University and the Kenya Institute of Mass Communications. Controversially, however, the council is charged with accrediting (i.e. licensing) all journalists, and is also investigating the accrediting of journalism schools and journalism teachers (see Berger, 2009). In this case, while bridging is clearly tempting for the participants in terms of connections, status, and other possible benefits to their institutions, it may risk compromising their independence as well as the potential for collegiate values within the wider journalism education sector in Kenya.

\footnotetext{
${ }^{5}$ An exception here has been the six colloquia of educators (some national, some pan-African) convened over seven years by Rhodes University since 2003.
} 
Another case of networking is the ACCE, noted earlier, which had been a network of broadbased communications teachers and researchers with members in the diaspora and Kenya, Nigeria, Ghana, and Cameroon amongst others. It declined, due to poor governance and a funding fall-off in the second half of the 1990s. One chapter that has continued to thrive is that in Nigeria, and a revival conference was convened in Ghana in 2009. Although 73 papers were accepted at that conference, and the further advantage of involving African media scholars from abroad, there was little that directly served journalism educators and not much that emerged subsequently in terms of pan-African networking. One reason was the wide range of communications interests entailed in ACCE (like SACOMM) and another is the difficulty of sustained organising on a pan-African scale without having resources or dedicated leadership. One lesson learned from the ACCE experience is that successful networking of journalism educators may well need to rely on a narrower focus and on affirmation of a more distinctive identity than that of African communications scholar.

\section{The experiences of UNESCO and the WJEC Prepcom}

UNESCO has some history in supporting African journalism education (see Berger, 2007, 2008b). However, in 2007 it commenced a new initiative that led to a degree of networking. In this, the focus commenced with linking across national boundaries (as distinct from bonding and bridging). The exercise originated with the development of UNESCO criteria for excellence for specifically African journalism schools, and it elicited involvement by persons attached to 19 journalism schools from 12 countries around Africa. This was enabled by email and partly by participation in a Yahoo discussion forum (http://groups.yahoo.com/group/UNESCOAJ)_over a period of approximately two months, with deliberations on draft criteria. A total of 30 African schools from 17 countries then completed the resulting checklist with each hoping to be deemed a centre of excellence (See Berger \& Matras, 2007).

In all this, the linking of initially different participants, largely unknown to each other, led to bridging based on a common cause of Pan-African remit, which transcended both national and language divides (Anglophone and Francophone). Enabling this networking to happen was UNESCO-funded and -initiated agency in the form of this author and Corinne Matras 
from the French École Supérieure de Journalism Lille (ESJ). The activity entailed translation, aggregation, production of new drafts, and much chivvying of participants to give time to the project. A primary reason for the success of networking activity, it can be proposed, was the potential linkage it provided to UNESCO. The prestige of this international organisation, and the potential to acquire resources through it, seems to have been a driving force for people to set aside scarce time to be involved in a shared endeavour. Indeed, the contribution made by the different participating institutions paid off when UNESCO identified 19 schools that were deemed to have "potential" for excellence, many of which subsequently received financial support from the organisation.

The group of UNESCO-identified schools was also brought together in a conference hosted in South Africa at Rhodes University in March 2008. Several participants there argued strongly that relationships should be formalised by setting up an organisation (see Berger \& Kyazze, 2008). The gathering, however, declined such ambitions, citing the experience of the ACCE. However, the occasion had also been designed as an opportunity for participants to develop bridging relationships with journalism schools outside of Africa as well as linking relationships with donor agencies. There was participation by representatives of US, UK, French, and Australian journalism schools as well as by potential donors from the Netherlands, US, UK, and South Africa. A number of actual (though mainly short-term) relationships and activities eventually materialised out of this (see Berger 2008).

The March 2008 meeting recommended that the schools work towards developing their potential through joint projects such as research on topics like media and conflict. To follow up this point, a follow-up meeting was attended in September 2008 by eight of the UNESCOnamed centres. Ten advance contributions solicited from delegates allowed for common areas of research to be identified (such as media and democracy) (See Berger, 2008a). At the meeting itself, proposed collaborations included exploring what epistemological and ontological issues informed journalism education on the continent. Participants agreed finally to create detailed databases of research output and of staff expertise which could then enable schools to identify external examiners amongst each other. There was also a decision to investigate staff exchanges and to work on syllabi for modules in Mass Media and Society 
and Research Methods, which would be relevant to African conditions. In addition, there was to be a project on getting African media scholarship published and made more accessible. A research colloquium of students and senior scholars was proposed, as well as a focus on building strategic leadership in the schools, which would be part of a possible workshop to be convened in Namibia on 3 May 2009. Different individuals were allocated responsibility for each task area (See Berger, 2008a).

While this list of agreed activities could have contributed substantial social capital to the emerging UNESCO schools' network, only few of the plans materialised. One was the proposed meeting in Namibia. In part, its realisation may have been a function of people responding to invitations to go to new places and to the resourcing and prestige provided by UNESCO's continued involvement. The UNESCO-recognised schools at the Namibia Polytechnic and the University of Namibia did the organising, and Rhodes raised the funds from the Open Society Institute of West Africa and UNESCO. This gathering drew 25 educators from 12 countries (see Gómez de Sibandze \& du To, 2008). The focus was on both strategic leadership and how new media impacted upon the curriculum.

Akin to the Namibian institutions contributing their time to organising African journalism educators, the journalism school at the University of Stellenbosch marked its $30^{\text {th }}$ anniversary with a seminar in October 2008 that invited selected educators from eight of the UNESCOrecognised schools in other parts of Africa. This was achieved with the support of funding from the school's long-standing ties to South African company Media24. In October 2009, the journalism school at the University of the Witwatersrand took the initiative to organise a limited-participation "Conference of African Journalism Educators" with the assistance of the contact list built up by Rhodes University's journalism school. This event involved some 20 participants from around the continent and received support from the Konrad Adenauer Stiftung (KAS). That gathering formed a loose grouping called the "Forum of African Media Educators" (FAME), and 10 members who had papers accepted for the WJEC were later sponsored by the KAS to attend the Congress (and also take part in a separate workshop on academic skills for writing conference papers). 
In other words, while networking in 2008 failed to generate social capital to carry forward various project activities, it did nevertheless show some fruit in terms of boosting reciprocity as evident in terms of three separate knowledge-based meetings being convened. Key ingredients in the recipe for success were the bridges and linkages by active schools to sources of external resources. In sum, the existence of connections to UNESCO, Open Society Institute of West Africa, Media24, and the KAS were what enabled the events to happen.

For September 2009, African journalism educators were invited to present papers to a research colloquium to be bundled into a Preparatory Conference (Prepcom) for the World Journalism Education Congress (WJEC), that in turn was scheduled for 2010 at Rhodes University (see Banda, 2009). This colloquium paralleled the $13^{\text {th }}$ Highway Africa conference (the world's largest annual gathering of African journalists) and drew in part from the extensive resource linkages of this institution. A total of 32 peer-reviewed papers were presented at the colloquium from delegates hailing from nine African countries (and from three educators in the diaspora). The presenters represented a total of 21 journalism schools across the continent, and 83 educators attended in total. Packaged with sponsored attendance was complimentary attendance at the prior Highway Africa events, which provided an opportunity to bridge with practising journalists from around the continent. The follow-up of the colloquium was straightforward -- to re-work the papers for submission to an international selection panel for presentation at the WJEC itself at Rhodes in July 2010. UNESCO also used the colloquium to launch their new social networking website for African journalism educators (http://journalismschools.unesco-ci.org/), which was agreed upon as an online venue for discussion about developing a model syllabus for a course on Reporting Africa to be presented at WJEC.

In terms of follow-up, of the 38 people who presented papers at the colloquium, 11 had abstracts accepted for the WJEC. Given the purpose of the "Prepcom" character of the colloquium in relation to the WJEC, this was not a strong throughput if measured directly. On the other hand, there was a total of 57 abstracts from Africans in general which the WJEC 
accepted, within the 160 paper acceptances worldwide. This seems to indicate that some momentum had built up in terms of African educator interest in attending the WJEC.

For its part, however, the model syllabus initiative drew minimal participation. This was despite it being billed at the Prepcom as a pan-African collaboration that would benefit not only journalism education around the continent but also constitute a resource for colleagues abroad who might want to offer modules relating to African journalism. It is fair to conclude that this collective project experienced the same lack of traction as the projects agreed to by the schools in September 2008. This was even though it enjoyed UNESCO's website availability and funding for the base research (See Banda 2010, UNESCO 2010). Finally, the initiative was intended to capitalise on a sense of identity as African journalism educators who felt concerned at how the continent is marginalised and misrepresented in much media (both abroad and at home). However, just a handful of educators commented on the need for such a curriculum, and the four modules produced received very little feedback. One reason, gleaned anecdotally, was the complexity of the UNESCO website, and another was simply that the initiative did not engage the imagination and elicit the time commitment of the continent's educators. Pan Africanism on its own, it seems, is not a sufficient sentiment to enable effective social networking in practice. Another limiting factor may have been that the exercise was not presented as having any follow-up -- for example, potential future resourcing for further syllabus development across many additional African media topics.

\section{Conclusion and the WJEC itself}

While many obstacles militate against networking African journalism educators, this article suggests that these can be transcended in certain instances. Assessing the experience to date, one can provisionally point to drivers of effective networking, and to factors that limit the success thereof. The factors in favour of successful networking seem to hinge on simplicity, focus, travel, and (especially) the mobilisation of third-party resources and prospects for subsequent resources. Conversely, language barriers, lack of resources, and time constraints limit successful networking, which is compounded when follow-up activities involve complex and time-consuming work, such as collecting and sending data, or contributing comment, without evident specific future benefit for the contributor. There is also lesser 
interest in smaller activities as distinct from "grander projects" like Africanising the curriculum, learning new media, and presenting a strong African front at the WJEC.

There is no focused evaluation of how the WJEC itself specifically contributed to networking African journalism educators, beyond widely expressed sentiments that there should be a significant presence of the sector at the third Congress to be held in 2013. However, several observations can be proffered.

Firstly, educators from Africa constituted a noticeable presence at the WJEC. Of the 54 countries represented at WJEC, 23 were African. Of the 393 delegates in attendance, 170 were African. The bulk of these were able to attend through funds raised by Rhodes from UNESCO, various foundations, companies, and the South African tourism and marketing agencies. This mobilisation relied on linkages built by Rhodes over several years, and also on the momentum of ongoing work over that period with African journalism educators. The Congress accepted 139 abstracts for papers, of which 57 were from Africans (most submitted without definite certainty of funding of attendance). Of the total of 90 papers actually presented at the event, almost half (44) were delivered by Africans.

Five of the six panel sessions involved African speakers, and there was also the launch of the model Reporting Africa syllabi. Amongst specific African value-add events at WJEC were four courses pre-, post- and during the conference itself, involving some 50 educators from the continent (and covering new media, economics journalism, and academic research paper writing). UNESCO convened a one-day meeting of its centres, and there was also a research paper session under the auspices of FAME. Several exhibitions included African issues and publications, and four books were launched on African media topics. All these activities would have added to the sense of identity and importance of journalism education in Africa.

Other African issues were also prominent at the start and the end of the event. The African Union's Special Rapporteur for Freedom of Expression, Advocate Pansy Tlakula, called on educators and journalists to regard non-mainstream sexual orientations (a controversial issue in some African countries) as part of the exercise of freedom of expression. Bishop Desmond Tutu urged journalism schools to promote press freedom. He also became the first dignitary 
to sign the 'Table Mountain Declaration' that calls for an end to insult laws and criminal defamation in Africa. Tutu's signing up to this cause showed that journalism educators could contribute significantly to a campaign waged under the auspices of the World Association of Newspapers (WAN-IFRA) and the World Editors Forum (WEF) that had hitherto been confined to the media industry. The fact that the WJEC event paralleled the $14^{\text {th }}$ Highway Africa conference entailed interactive bridging with the media industry.

In terms of more specific gains, social capital creation was evident from the remarks of one delegate who commented in the general conference evaluation: "I got to meet some big names in the journalism academic field and interact with them. I also got contacts that will help me in organizing conferences here in Kenya." Several seeds were also planted for nonAfricans in relation to their African counterparts. One conference evaluation comment by a non-African participant at WJEC stated: "I liked the chance at research panels and dinners to talk with journalists and journalism educators from Africa and elsewhere and, in the process, diminish my ignorance." Another said: "I am planning a trip around the USA to interview people about issues of identity; I enjoyed two research panels that focused on issues of African identity."

In general, all these data suggest that the WJEC helped to bring a number of African educators into the mainstream of global journalism education, to contribute their experiences and contacts to the global community, and that the experience promoted their knowledge and over-arching identity of this constituency. Whether the WJEC led to sustained bridging between African journalism educators of different languages and countries is not clearly evident. However, one early follow-up that was inspired by the event was UNESCO support for a workshop on the issue of journalism education and neglected indigenous languages. Further research would be needed to ascertain whether any such bridging deepened bonding and whether this was a function of constituency members to execute further social networking through interest and capacity.

Although South African historical experience of networking journalism educators suggests that bridging (to industry) can be more successful than bonding (with each other), it is also possible that intra-African bridging amongst schools or individuals could be both a pre- 
condition and foundation for diverse external linkages. (These linkages could be to international colleagues, to local industry, or to donors). Indeed, learning from the experiences reviewed in this paper, bridging and linking can generate resources of direct value to a given participant, and this can be done on the basis of building intra-African connections via linkage to third parties. In this way, external networking may help contribute to intra-sectoral bridging and even bonding. However, if it is to move to the next level, African journalism educator networking needs to generate more sustainable participation, leadership, activities, and especially tangible benefit to the participants (including benefit that goes wider than knowledge gains such as conferencing). To do this, reciprocity is a key element that is needed to grow social capital in the sector. More participants will have to invest in making networking valuable for others if they themselves wish to gain from such connections. If bridging (and bonding) within the constituency is an effective way to link to external resources, this may become the key to enduring relationships with deepening productivity. This may be an expedient rationale for intra-sectoral networking but, after all, connecting journalism educators is not an end in itself. It is about generating social capital that can unlock other kinds of capital -- whether prestige, knowledge, skills, experiences, collaborations, technology flows or monetary injections. In this way, a successful network of African journalism educators may rely on resources, but it can also generate further resources.

Anecdotal feedback about the success of WJEC in an African country is that its success was a source of pride for many educators on the continent. In other words, inequality between Rhodes University as host, and other African journalism schools as sponsored attendees, does not appear to be a source of distrust. Likewise, rivalry amongst South African institutions nevertheless saw collaboration with Wits University over the FAME presence at WJEC and the participation of many other educators across the country. Furthermore, it was also evident that journalism educators on an international scale, and especially including Africans, could come together and take themselves and each other seriously. This generated a great sense of purpose and excitement about being part of a global constituency (Berger 2010a, 2010c). A respondent to the WJEC evaluation questionnaire wrote: "The exposure to various practices and research projects undertaken by senior journalism educators demonstrated that these educators take their job seriously and they are worthy of training future journalists." It 
can be posited that this sentiment reflects pride in an identity -- not least one in relation to stakeholders like African journalists, various donors and sponsors, UNESCO, and to global media associations like WAN and WEF. This constitutes potential to reap further relationship-building of relevance by means of continued networking of African journalism educators. Progress has been made towards building a sense of collective identity, and an appreciation of networking, amongst African journalism educators. Further research could establish the extent to which there is growing self-awareness of their collective value as a distinctive and living community of practice.

\section{About the author:}

Prof. Guy Berger was the Head of School of Journalism \& Media Studies at Rhodes University, Grahamstown, South Africa between1994-2010. His ongoing research is available online at: http://guyberger.ru.ac.za/)

Email address: G.Berger@ru.ac.za

\section{References:}

Amner, R. (2010). Taking a "Leap": Exploring student learning and identity formation on a praxis-based journalism course. Retrieved 25 August 2011 from the World Web: http://wjec.ru.ac.za/index.php?option=com_rubberdoc \&view=doc\&id=12\&format=raw \&Ite $\operatorname{mid}=45$

Banda, F., Beukes-Amiss, C.M., Bosch, T., Mano, W., McLean, P. \& Steenveld, L. (2007). Contextualising journalism education and training in Southern Africa. Ecquid Novi: African Journalism Studies, 28 (1\&2): 156-173.

Banda, F. (2009). Towards an African agenda for journalism education. Presentation to WJEC African Prepcom, 9 September 2009. Grahamstown, Rhodes University. Retrieved from the World Wide Web: http://wjec.ru.ac.za

Banda, F. (2010). A conceptually relevant and practically sophisticated journalism syllabus for Africa. Rhodes Journalism Review, (30): 17-18. Retrieved 25 August 2011 from the World Wide Web: http://www.rjr.ru.ac.za/rjrpdf/rjr_no30/Journ_syllabus_for_africa.pdf

Berger, G. (2007a). In search of journalism education excellence in Africa: Summary of the 2006 Unesco project. Ecquid Novi. 28 (1\&2): 149-155 
Berger, G. (2007b). African journalism meets ICT: whither the wealth of networks?

Presentation to seminar at University of Queensland, School of Journalism and Communications. 16 August 2007.

Berger, G. (2008a). (with Denis Ocwich). A Report of a Follow-up Meeting of UNESCO jschools, held September 11, 2008 at the School of Journalism and Media Studies, Rhodes University, Grahamstown, South Africa. Grahamstown: UNESCO and Rhodes University. Retrieved 25 August 2011 from the World Wide Web: http://nml.ru.ac.za/files/Unesco\%20jschools\%20September\%20meeting\%20report\%20final.doc

Berger, G. (2008b). Towards defining 'Potential Centres of Excellence' in African journalism training. Journalism Practice, 2(2): 147-162.

Berger, G. (2009). How to improve standards of journalism education. African Communication Research. 2(2): 271-290.

Berger, G. (2010a). J-teachers getting their international act together, Rhodes Journalism Review, (30): 3-4. Retrieved 25 August 2011 from the World wide Web: http://www.rjr.ru.ac.za/rjrpdf/rjr_no30/JTeachers_get_int_act_together.pdf

Berger, G. (2010b). Social organising of African journalism educators. In "Focus on FAME, an RJR special feature", Rhodes Journalism Review, (30): 11.

Berger, G. (2010c). Journalism teachers building a global community. Journalism and Mass Communication Educator, 65(2): 158-167.

Berger, G. \& Kyazze, S. (2008). Consultation meeting: Capacity building for potential centres of excellence in journalism training in Africa Report. Rhodes University, South Africa, 17-18 March. Retrieved 25 August 2011 from the World Wide Web: http://unesdoc.unesco.org/images/0016/001628/162818e.pdf. Also at: http://nml.ru.ac.za/files/FINAL\%20REPORT\%20African\%20Journalism\%20Schools\%20con sultation\%2011.pdf

Berger, G. \& Matras, C. (2007). Criteria and indicators for quality journalism training institutions \& identifying potential centres of excellence in journalism training in Africa. By www.unesco.org/webworld/en/african-journalism-schools-report Also at: http://portal.unesco.org/ci/en/ev.phpURL_ID=24846\&URL_DO=DO_TOPIC\&URL_SECTION=201.html

Botha, N. and de Beer, A.S. (2006). Revisiting South African journalism education in the post-apartheid era. Global Media Journal-Polish Edition, No. 1, Spring.

Bourgault, L.M. (1995). Mass media in sub-Saharan Africa. Indiana: Indiana University Press. 
Bourdieu, P. (1980). "Le Capital Social” in Actes de la Recherche en Sciences Sociales. 31: 2-3.

Bourdieu, P. \& Wacquant, L. (1992). An invitation to reflexive sociology. Chicago: University of Chicago Press.

Claussen, D.S. (2008). Assessing and discussing Excellence in African Journalism Education Journalism \& Mass Communication Educator. 63 (1). Editor's Note. Retrieved 25 August 2011 from the World Wide Web; http://www.aejmc.org/JMCEfolder05/JMCE/vol63/issue1/claussen.html

Coleman, J. (1998) [1988]. Social capital in the creation of human capital. In E. L. Lesser (Ed), Knowledge and social capital: Foundations and applications. Boston, Ma.: Butterworth Heineman.

De Beer, A.S. (2010). Looking for journalism education scholarship in some unusual places: The case of Africa. Communicatio 36 (2): 213-226.

Dube, B. (2010). Africanising journalism curricula: the perceptions of southern African Journalism scholars. Retrieved 25 August 2011 from the World Wide Web: http://wjec.ru.ac.za/index.php?option=com_rubberdoc \&view=doc\&id=57\&format=raw \&Ite $\operatorname{mid}=45$

Field, J. (2003). Social Capital. London: Routledge.

Fosu, M. (2010). Situating language in the center of journalism training: The case for broadening the spheres of English teaching and learning in journalism training institutions in Ghana. Retrieved 25 August 2011 from the World WideWeb:

http://wjec.ru.ac.za/index.php?option=com_rubberdoc\&view $=$ doc $\&$ id $=58 \&$ format $=$ raw $\&$ Ite $\operatorname{mid}=45$

Gómez de Sibandze, E. \& du To, J. (2008). Media trainers workshop report. 5-6 May 2009. Polytechnic of Nambia. Unpublished.

Hochheimer, J.L. (2001). Journalism education in Africa: from critical pedagogical theory to meaning-based practice. Critical Arts. 15 (1\&2): 97-116.

McCurdy, P.M. \& Power, G. (2005). Journalism education as a vehicle for media development in Africa: The AMDI project. Ecquid Novi: African Journalism Studies. 28(1\&2): 127-14.

Mojaye, E. M. (2009). Location of mass communication and communication studies in Nigerian universities, Journal of Communication and Media Research. 1 (2): 217- 229.

Murphy, S. \&. Scotton, J. (1987). Dependency and journalism education in Africa. Are there alternative models. Africa Media Review, 1(3):11-35. 
Njugana, W. (2010). Broadening horizons: A case study of a training newspaper at the University of Botswana. Retrieved 25 August 2011 from the World Wide Web; http://wjec.ru.ac.za/index.php?option=com_rubberdoc\&view=doc\&id=51\&format=raw\&Ite mid $=45$

Nyamnjoh, F. B. (2005). Africa's media: Democracy and the politics of belonging. London: Zed Books.

Okigbo, C. \& Pratt, C. B. (1997). Curricula for media education in Anglophone Africa. Journalism and Mass Communication Educator, 52 (3): 8-15.

Olusola, O. O. (2010). Teaching journalism in a proliferated system: the state of journalism education in Nigeria. Retrieved 25 August 2011 from the World Wide Web:

http://wjec.ru.ac.za/index.php?option=com_rubberdoc \&view=doc\&id=50\&format=raw \&Ite mid $=45$

Oyelele, A. (2011). Journalism education, Pan-Africanism, and the quest for Africa's modernity. African Communication Research, 4 (1): 175- 202.

Popoola, M. (2010). Journalism education curricula models: An analysis of CTT of four programmes in Nigerian universities. Retrieved 25 August 2011 from the World Wide Web: http://wjec.ru.ac.za/index.php?option=com_rubberdoc \&view $=$ doc $\&$ id $=56 \&$ format $=$ raw $\&$ Ite $\operatorname{mid}=45$

Putnam, R D. (2000). Bowling alone: The collapse and revival of American community. New York: Simon and Shuster.

Rabe, L. (2005). Reflection on mapping the curriculum -- towards Afro-humanist values in identifying "new basics" in South African journalism. Paper presented at a colloquium on "Taking Stock: 10 years of media education and training", Rhodes University, South Africa.

Rooney, Richard (2007). Revisiting the journalism and mass communication curriculum: Some experiences from Swaziland, African Journalism Studies, 28 (1\&2): 207-221.

Sibanda, B. (2010). Twenty years of journalism education in the Southern African development region (SADC): A comparative review study, 1989-2009. Retrieved 25 August 2011 from the World Wide Web:

http://wjec.ru.ac.za/index.php?option=com_rubberdoc \&view=doc\&id=55\&format=raw \&Ite $\operatorname{mid}=45$

Skjerdal, Terje. (2009). Between journalism universals and cultural particulars: challenges facing the development of a journalism programme in an East African context, Journal of African Media Studies, 1(1), 23 -34. 
Skjerdal, T. \& Ngugi, Charles, M. (2007). Institutional and governmental challenges for journalism education in East Africa, African Journalism studies, 28 (1\&2): 176-189.

Taschereau, S. and Bolger, J. (2006). Networks and capacity. A theme paper prepared for the study "Capacity, Change and Performance". European Centre for Development Policy Management: Maastricht. Retrieved 25 August 2011 from the World Wide Web;

http://www.dgroups.org/groups/pelican/docs/Bolger_Taschereau_networks_and_capacity_20 06.pdf, at 30/10/08

UNESCO. (2007). Database of African journalism schools. Retrieved 25 August 2011 from the World Wide Web: www.unesco.org/webworld/en/african-journalism-schools-database

UNESCO. (2010). Reporting Africa. http://journalismschools.unesco-

ci.org/pg/pages/view/29667/reporting-africa

Wimmer, J. \& Wolf, S. (2005). Development journalism out of date? An analysis of its significance in journalism education at African universities. Available on the World Wide Web: http://epub.ub.uni-muenchen.de/647/1/mbk_3.pdf

Wuite, R. (2008). What makes the Net Work? A conceptual network capacity analysis. Unpublished Masters Thesis, University of Amsterdam.

* The paper revises and updates an initial version presented at the World Journalism Education Congress, Grahamstown, July 2010 (an abridged version was published at Berger, 2010b). 